\title{
MENGUKUR EFEKTIVITAS SOCIAL MEDIA BAGI PERUSAHAAN
}

\author{
Kuspuji Catur Bagus Wicaksono \\ Management Department, School of Business Management, BINUS University \\ Jln. K. H. Syahdan No. 9, Palmerah, Jakarta Barat 11480 \\ gundamocil12@yahoo.com
}

\begin{abstract}
Enterprises have a new tool in conducting marketing activities to reach more targeted consumers, which is social media. Social media provides a wide range of alternatives for entrepreneurs and companies in conducting marketing activities, which has more interaction and more social to consumers. However, in doing so it is not carelessly, because it must take into consideration the use of measurement and the benefits that would be obtained by using social media. Recently, there are many existing measurements. However, along with the development of the information technology, means to do marketing have to develop also.
\end{abstract}

Keywords: social media, Internet marketing, viral marketing, integrated marketing communication

\begin{abstract}
ABSTRAK
Perusahaan bisnis mempunyai sarana yang baru dalam melakukan kegiatan pemasaran untuk mencapai lebih banyak konsumen yang dituju, yaitu Social Media. Social media memberikan berbagai macam alternatif bagi entrepreneur dan perusahaan dalam melakukan kegiatan pemasaran, yang lebih berinteraksi dan lebih sosial kepada konsumen. Akan tetapi dalam melakukannya tidak sembarang, karena harus mempertimbangkan pengukuran penggunaan dan manfaat yang akan diperoleh dengan menggunakan social media. Untuk sementara sudah banyak cara pengukuran yang ada. Namun, seiring dengan perkembangan dari sisi teknologi informasi, cara untuk melakukan pemasaran juga harus mengalami perkembangan.
\end{abstract}

Kata kunci: social media, Internet marketing, viral marketing, integrated marketing communication 


\section{PENDAHULUAN}

Perusahaan menggunakan kreativitas untuk menghasilkan atau mengelola sesuatu menjadi bernilai ekonomis. Bernilai ekonomis karena mempunyai calon pelanggan yang akan membeli baik berupa produk atau jasa yang diciptakan. Tentunya bagi pelanggan atau konsumen untuk dapat membelinya, perusahaan terlebih dahulu harus memasarkan produk atau jasa tersebut. Hal ini perlu dilakukan agar calon pelanggan atau konsumen mengetahui keberadaan dari produk atau jasa tersebut. Langkah pemasaran yang dapat dilakukan baik dari hal yang paling sederhana seperti pembuatan dan penyebaran media brosur atau pamflet ke lingkungan masyarakat dengan harapan dari berlembarlembar brosur dan pamflet tersebut akan menarik perhatian dan keingintahuan calon konsumen atau pelanggan. Akan tetapi dengan menggunakan cara ini hanya akan menjaring konsumen di tempat brosur atau pamflet tersebut disebarkan. Padahal potensi calon konsumen atau pelanggan tidak hanya di sekitar lingkungan tempat usaha entrepeneur tersebut dibuka. Jangkauan daerah potensi konsumen juga bisa lebih luas lagi, dan terkadang daerah yang di luar penyebaran pamflet merupakan konsumen atau pelanggan potensial.

Untuk menjaring konsumen/calon konsumen, perusahaan mempunyai pilihan dengan menyebarkan brosur atau pamflet juga, namun hal tersebut akan menambah biaya pemasaran. Perusahaan mempunyai pilihan lain yaitu dengan menggunakan media elektronik; media tersebut adalah Internet. Dengan menggunakan media Internet, pemasaran akan lebih langsung menuju calon konsumen atau pelanggan yang dituju. Para calon konsumen/calon pelanggan bisa mendapatkan informasi lebih dengan menggunakan Internet dibandingkan menggunakan media elektronik atau cetak lainnya. Maka dari itu, perusahaan dalam menjaring baik konsumen dan calon konsumen atau pelanggan baru dapat menggunakan media elektronik berupa sosial media dalam melakukannya.

\section{Landasan Teori}

Brand atau merek menurut Asosiasi Pemasaran Amerika (Mohammed, 2002:508) adalah: "A name, term, sign, symbol, or design or a combination of them, intended to identify the goods or services of one seller or group of sellers and to differentiate them from those of competitors." Atau dengan kata lain, brand atau merek adalah nama, istilah, tanda, simbol atau gabungan dari semuanya, berguna untuk mengidentifikasi sesuatu produk atau jasa dari satu atau kelompok penjual dengan pesaingnya. Brand atau merek merupakan janji dari penjual untuk memberikan pelayanan yang sesuai dengan yang telah ditetapkan. Makin bagus brand atau merek, maka makin bagus kualitas garansi maupun pelayanannya.

Aaker dan Joachimsthaler (Mohammed, 2002:545) mengatakan bahwa situs Internet merupakan bagian yang signifikan dalam program brand-building, karena dapat mengomunikasikan informasi, association, dan keuntungan dari aspek lain strategi brand. Salah satu kunci manfaat dari situs Internet dibandingkan lainnya adalah lingkungan yang terkendalikan. Konsumen memilih untuk masuk ke dalam situs tersebut dengan mengklik link atau secara tidak langsung melalui web link. Mereka juga dapat memilih tujuan dari lama waktunya di situs tersebut, dan mereka lebih terlibat dengan proses dan pesan dari suatu brand.

Brand Equity adalah kombinasi dari tanggapan dan manfaat dari konsumen, kombinasi aset yang dapat dilihat dari pandangan konsumen dan perusahaan. Hubungan antara kinsmen dan brand, yang di dalamnya konsumen dapat mengevaluasinya secara berbeda dengan brand lainnya, juga sekumpulan aset atau piutang yang konsumen nilai.

Brand Identity menurut Aaker (1996:68) adalah sekumpulan brand association yang unik untuk membuat atau memelihara brand tersebut dilakukan oleh para brand strategist. Asosiasi ini 
menggambarkan kesan yang dibawa oleh suatu brand dan janji yang akan diberikan entrepreneur atau perusahaan kepada konsumen. Identitas dari suatu brand memberikan petunjuk, tujuan, dan maksud dari brand tersebut. Brand identity dapat membantu dalam hubungan antara brand itu sendiri dengan konsumennya melalui manfaat yang diberikannya.

Sehingga untuk menyampaikan brand tersebut ke konsumen, Social Media bagi entrepreneur dilatarbelakangi perubahan teknologi dan perilaku individu, organisasi. Mengubah cara pendekatan entrepreneur dalam melakukan pemasaran terhadap usahanya sehingga untuk dikenal lebih detail oleh para konsumen.

Social media (Wikipedia, 2013) adalah sarana untuk berinteraksi antara individu tempat mereka menciptakan, berbagi, bertukar, dan memberikan komentar terhadap satu dengan lainnya di dalam lingkungan dan jaringan maya. Andreas Kaplan dan Michael Hanelein (2010) mendefinisikan Social media adalah sekelompok aplikasi dengan berbasis Internet yang diciptakan menggunakan ideologi dan teknologi dari Web 2.0, dan memperbolehkan penciptaan dan pertukaran konten yang dibuat oleh user. Social media menggunakan mobilitas dan teknologi berbasis web untuk menciptakan sebuah media yang interaktif tempat individu dan komunitas dapat berbagi, menciptakan, mendiskusikan, dan memodifikasi konten tersebut. Hal ini memperkenalkan dan mengubah cara berkomunikasi antara organisasi, komunitas dan individu.

Menurut Safko dan Brake (2009), social media mengacu pada kegiatan dan perilaku di kalangan komunitas orang-orang yang bertemu secara online untuk berbagi informasi, pengetahuan dan pendapat menggunakan media percakapan. Media percakapan adalah aplikasi berbasis web yang memungkinkan dengan mudah membuat dan mengirimkan konten dalam kata-kata, gambar, video dan audio.

Menurut Solis dan Breakenridge (2009:xvii), social media adalah kebebasan informasi dan pergeseran peran orang dalam proses membaca dan menyebarkan informasi yang didukung oleh teknologi web 2.0. Social media memberdayakan masyarakat untuk menjadi penyebar informasi. Social media merupakan pergeseran penyebaran informasi dari mekanisme broadcast (one to many) menjadi mekanisme many to many. Menurut Mayfield (2008), social media paling baik dipahami sebagai suatu kelompok baru dari online media, yang sebagian besar memiliki karateristik sebagai berikut: (1) Participation \& Engagement, social media mendorong kontribusi dan umpan balik dari semua orang yang tertarik. Hal ini mengaburkan batas antara media dan audiens. (2) Openness, sebagian besar layanan social media terbuka untuk menerima umpan balik dan partisipasi. Media social mendorong suara/voting, komentar, dan berbagai informasi. Terdapat sedikit hambatan untuk mengakses dan membuat konten, bahwa konten tersebut dilindungi dengan password dari pengguna. (3) Conversation, bila tradisional media berbicara tentang komunikasi broadcast (konten yang ditransmisikan atau didistribusikan kepada audiens), social media berbicara tentang komunikasi yang lebih baik, yaitu menggunakan metode percakapan komunikasi 2 arah. (4) Community; Social media memungkinkan komunitas untuk terbentuk dengan cepat dan dapat berkomunikasi dengan efektif. Komunitas dapat berbagi minat yang sama, seperti pencinta fotografi, olahraga, atau sebuah acara tv favorit. (5) Connectedness; social media berkembang karena keterhubungan mereka satu dengan lain dengan cara memanfaatkan link yang mengarahkan untuk berpindah ke sumber website yang lain.

Website social media mampu mengakomodasi keinginan pengguna untuk berinteraksi secara interaktif dan berpartisipasi pada yang mereka minati atau geluti. Karena kelebihan cara berkomunikasi yang interaktif serta jangkauan global yang dimiliki social media, saat ini banyak perusahaan baik nasional maupun multinasional memanfaatkan social media untuk melakukan komunikasi pemasaran produk/jasa yang dijual kepada para pelanggan. Interaktivitas menumbuhkan arti baru ketika hal itu diterapkan melakui teknologi web 2.0 dan social media sebagai dialog konsumen dan perusahaan sehingga menjadi lebih aktif dan interaktif (Ivanauskas, 2009). Armano (2008) berpendapat bahwa social media melampui pemasaran interaksi antara komputer-manusia dan 
memperkenalkan interaksi manusia ke manusia yang dilakukan melalui saluran online Social media dan menghasilkan konten baru tentang perusahaan (blogging, komentar, jejaring sosial, dan lainlainnya).

Zarrella (2010:3) berpendapat bahwa social media mempunyai banyak bentuk, namun untuk tujuan pemasaran terdapat 8 macam bentuk social media yang paling banyak digunakan yaitu: Pertama, Blog; adalah website yang isinya berupa tulisan-tulisan yang merupakan opini dari pemilik blog. Biasanya blog disajikan berurutan berdasarkan tanggal. Tulisan terbaru yang dibuat, dimunculkan di paling atas. Ciri lain dari blog adalah adanya komentar. Pembaca blog bisa memberikan tanggapan terhadap isi tulisan. Penulis blog bisa memberikan balasannya pula di bagian komentar itu. Mulai populer pada 1999, ketika situs LiveJournal dan Blogger diluncurkan. Pengguna bisa mendaftar ke salah satu situs penyedia layanan blog dan memluai membuat blog sendiri secara gratis dan tanpa memerlukan kemampuan teknis yang tinggi (Chandra, 2012).

Adapun karakteristik dari suatu Blog adalah sebagai berikut. (a) Posts, blog terbuat dari posting yang dilakukan oleh pengguna, bisa terdiri dari 100 kata, 200 kata atau lebih untuk membentuk beberapa halaman. Untuk efektif harus mengacu pada satu topik tertentu dan konsistensi juga kualitas dari posting. (b) Permalinks, setiap posting di blog bisa dilihat dari berbagai tempat termasuk halaman home, halaman kategori, dan archive. Halaman ini dihasilkan secara dinamis sehingga setiap posting baru akan muncul pada baris atau halaman pertama dalam blog tersebut. (c) Comments, pengguna dapat meninggalkan komentar. Komentar tersebut untuk membangun sebuah komunitas dan mendapatkan umpan balik. (d) Themes, memperbolehkan penggunanya untuk menyesuaikan tampilan situs melalui penggunaan tema. Blog yang memiliki tema yang unik akan membuat blog tersebut semakin populer, yang merupakan hal penting untuk membangun sebuah citra. (e) Archive and Category Pages, posting ditampilkan dalam urutan kronologis terbalik, biasanya hanya 10 atau 20 posting yang paling baru akan muncul pada halaman home suatu blog berdasarkan hari, minggu atau bulan. (f) Blogroll, daftar link ke blog lainnya yang direkomendasikan oleh pembuat blog tersebut. (g) Trackbaks or Pingbacks; aplikasi blog yang mengirimkan trackbacks atau pingbacks ketika pemilik blog menghubungkan blognya dengan blog lainnya. (h) Subscription, adalah suatu sistem sindikasi yang memungkinkan pengguna untuk mendapatkan update terbaru dari situs-situs favorit mereka secara otomatis. (i) Hosted vs Self-Hosted; hosted adalah blog yang berada pada server dimiliki oleh penyedia aplikasi blog. Sementara Self-hosted adalah blog yang dijalankan dengan cara menyewa hosting sendiri.

Kedua, Microblog, merupakan bentuk dari blog yang membatasi ukuran setiap posting, misalnya update Twitter hanya dapat berisi 140 karakter. Keterbatasan ini telah melahirkan seperangkat fitur dan perilaku yang sepenuhnya unik untuk media, digunakan oleh banyak perusahaan karena mudah digunakan, hanya memerlukan investasi waktu yang sangat sedikit, dan terbukti dapat dengan cepat menyebarkan informasi, penjualan dan wawasan pelanggan. Perusahaan dapat menggunakannya untuk melakukan penawaran atau peristiwa, dan mempromosikan posting baru dalam blog.

Ketiga, Social Networks, adalah sebuah situs tempat individu dapat terhubung dengan temanteman yang dikenalnya secara offline dan online ataupun dengan teman-teman yang hanya dikenal secara online saja. Media ini menjadi topik yang hangat bagi para pemasar, karena social networks hadir dengan sejumlah peluang untuk berinteraksi dengan pelanggan termasuk plug-in aplikasi, groups, dan fanpage.

Keempat, Media-Sharing Sites, sebuah situs berbagi media yang memungkinkan pengguna untuk membuat dan mengunduh konten multimedia. Dengan munculnya kemudahan dalam menggunakan kamera digital dan camcorder serta koneksi Internet berkecepatan tinggi, situs mediasharing telah menjadi sangat popular. Pemasar dapat membuat video dengan keahlian yang sangat kecil dan mengunduhnya ke situs seperti YouTube untuk menjangkau jutaan pengguna. Walaupun 
website jenis ini menyediakan fitur untuk bergabung menjadi anggotanya, sebagian besar dari pengguna situs tersebut bukanlah terdaftar anggotanya, tetapi hanya untuk sekedar melihat konten.

Kelima, Social News \& Bookmarking, sebuah situs yang memungkin pengguna untuk mengirim dan memilih konten dari seluruh situs tersebut. Hal ini untuk membantu mengetahui link yang paling menarik. Sehingga pemasar dapat menemukan situs yang banyak dikunjungi untuk mendorong penyebaran informasi dalam artikel atau kampanye pemasaran. Beberapa fitur yang membantu pemasaran yang ada di situs ini adalah seperti: profiles, berisi variasi profil pengguna yang menggunakan situs tersebut, sehingga mendapatkan informasi tentang konsumen tersebut; summitting, kegiatan yang untuk mengirim suatu konten, pengguna harus terdaftar di sebuah situs social news. Dengan ini pemasar bisa mengetahui konten yang paling banyak diminati oleh pengguna situs tersebut; votting, fitur menarik bagi pemasar untuk membantu melakukan pemasaran di dalam situs tersebut. Melihat konten yang paling popular diantara yang lain sehingga memberikan petunjuk bagi pemasar dalam menentukan konten yang dapat digunakan untuk menarik perhatian para konsumen; Headlines, fitur yang paling penting dan membawa efek paling besar pada seberapa banyak votting yang tertuju. Judul yang menarik akan memberikan kesan bahwa konten tersebut mudah dicerna, menghibur dan berharga. Judul harus eye-catching dan provokatif namun tidak menyesatkan.

Keenam, Review Sites, sebuah situs yang muncul karena berdasarkan survei April 2009 oleh Nielsen Media Research, mengatakan bahwa 70\% kepercayaan konsumen berasal dari pendapat konsumen yang sebelumnya telah membeli atau menggunakan dan diposting secara online, dibandingkan dengan $62 \%$ yang percaya pada iklan di TV, 61\% yang percaya pada iklan di surat kabar dan yang terakhir 59\% yang percaya pada iklan di majalah. Pada situs tersebut, penggunanya sudah berbicara mengenai produk, jasa dan brand online.

Ketujuh, Forums, merupakan jenis Social media yang merupakan versi modern dari papan buletin masyarakat. Fokus utama dari situs forums adalah mengenai diskusi yang terjadi di dalamnya antara anggota-anggotanya. Dalam hal ini, pemasar harus berhati-hati dalam memilih forum yang akan dimasukinya untuk melakukan kegiatan pemasaran karena umumnya para penggunanya tidak terlalu menyukai iklan.

Kedelapan, Virtual Worlds, sebuah situs yang di dalamnya berkisar pada permainan dan aktivitas sosial. Situs untuk pengguna bisa menjadi karakter yang diinginkan dan berinteraksi tidak hanya dalam lingkungan atau dunia permainan yang ada. Akan tetapi, kemungkinan untuk pemasar masuk ke situs ini untuk melakukan pemasaran sangat terbatas. Sehingga para pemasar lebih banyak masuk ke virtual world yang berjenis aktivitas sosial.

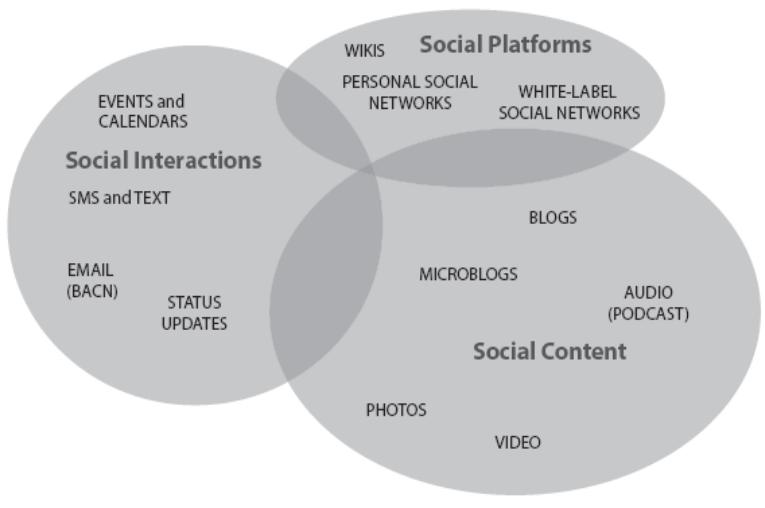

Gambar 1 Social Media Grouping

(Sumber: Evans, 2008:224) 


\section{Internet Marketing}

Internet Marketing (Wikipedia, 2013) atau dikenal dengan online marketing atau e-marketing adalah sarana pemasaran dan promosi produk atau jasa melalui media Internet. Menggunakan media tersebut dengan tujuan untuk mengantarkan pesan atau pemasaran ke konsumen yang lebih banyak. Definisi sederhana dari Internet marketing atau yang biasa disebut juga online marketing atau webmarketing (Wahyudi, 2009) adalah menjual barang atau jasa melalui media Internet. Online marketing dilakukan sebagai bagian dari bisnis offline. Konsumen akan lebih mengenalinya bila produkproduknya terpampang dan dilengkapi dengan email yang bisa digunakan untuk melakukan pemesanan sebagaimana halnya fungsi catalog tercetak pada bisnis offline.

Internet marketing juga bisa mewakili perusahaan dalam memasarkan produknya melalui dunia maya. Dengan Internet marketing bisa jadi pengusaha tidak perlu menyediakan kantor ataupun tokonya untuk menjual produknya. Bisnis melalui Internet bisa dioperasikan dari rumah sehingga biayanya bisa jadi sangat kecil dibandingkan harus sewa kantor atau toko. Dua hal penting yang harus dimiliki oleh Internet marketing adalah website dan email.

Sales website adalah bentuk terbaik dari Internet marketing. Perusahaan atau individu yang ingin membuat sebuah website akan memberikan kesempatan kepada konsumen untuk membeli produknya. Konsumen akan mengunjungi website, melakukan pemesanan, pembayaran secara online atau transfer via bank, dan barang akan dikirimkan ke konsumen. Semua transaksi ini akan dilakukan secara elektronik dan otomatis juga aman sehingga bisa memberikan rasa kepuasan tersendiri bagi konsumen. Proses pembelian ini dilakukan oleh konsumen tanpa harus meninggalkan rumah, cukup dilakukan dari depan komputer yang terhubung Internet.

Website informasi dibuat untuk menginformasikan tentang seluk beluk sebuah produk. Diharapkan dengan website yang berisi informasi tentang produk yang dijual akan memberikan penjelasan pada calon konsumen agar membeli produk yang dijual. Email marketing akan digunakan oleh pebisnis online untuk berkomunikasi dengan calon konsumen dengan memberikan penawaran. Pebisnis akan meminta izin kepada konsumen agar mau menerima setiap informasi yang akan dikirim melalui email tentang produk-produknya. Setelah konsumen setuju untuk menerima informasi itu, maka biasanya akan mengirimkan informasi/promosi via email tentang produk dan perusahaannnya dalam bentuk sales letter atau brosur.

Email marketing adalah cara yang paling mudah, murah dan efektif untuk mendistribusikan sales letter. Lebih ramah lingkungan dibandingkan mengirimkan kertas brosur ke alamat prospek. Akan tetapi, email marketing akan menjadi tidak efektif dan memberikan efek negatif jika pebisnis online melakukan spam.

Viral Marketing (dalam Anonim, 2010)

Viral marketing dipopulerkan oleh Tim Draper dan Steve Jurvetson dari perusahaan venture capital, Draper Fisher Jurvetson pada 1997 untuk menjelaskan kesuksesan marketing hotmail sebagai email provider. Viral dalam tinjauan marketing adalah terjadinya suatu tindakan baik kepada objek atau suatu pola pikir, sehingga memiliki kemampuan untuk menyebar dan menduplikasikan diri atau mengubah objek atau pola pikiran sehingga semakin menyerupai viral objek ketika berinteraksi dengan viral objek tersebut. Penyebaran ini bersifat eksponensial dan membentuk pola penyebaran virus biologis atau epidemis.

Menurut Ferrel, Hartline dan Lucas (2004:106) viral marketing adalah an electronic form of word of mouth communication. Viral marketing dapat diartikan sebagai suatu bentuk elektronik dari komunikasi dari mulut ke mulut. 
Menurut Armstrong dan Kotler (2004:90) "viral marketing is the Internet version of word-ofmouth marketing, that involves creating an E-Mail message or other marketing event that is so infectious that customers will want to pass it along to their friend." Dapat diartikan sebagai bentuk lain bahwa Internet dari penggunaan pemasaran dari mulut ke mulut, yang sangat berhubungan dengan menciptakan E-Mail atau cara pemasaran yang sangat menular sehingga konsumen mau menyampaikannya kepada teman mereka.

Menurut Turban (2004:193), viral marketing is word-of-mouth marketing by which customer promote a product or service by telling other about it. Dapat diartikan sebagai pemasaran dari mulut ke mulut dimana pelanggan mempromosikan sebuah produk atau jasa dengan cara menceritakan kepada orang lain.

Pengertian viral marketing menurut Arifin (2003:115) adalah suatu program yang dirancang seperti virus dan berjangkit dari satu orang ke orang lainnya secara cepat dan luas. Sedangkan pengertian Viral Marketing menurut Wiranaga (2002:95) Viral marketing merupakan perkembangan dari sistem direct selling dengan cara memberikan imbalan yang khusus dengan bentuk menyerupai network marketing atau Multi Level Marketing. Perbedaan viral marketing dengan Multi Level Marketing terletak pada variabel produk, perusahaan, harga, sistem bonus, iuran, target belanja, dan berbagai syarat lainnya.

Viral marketing saat ini adalah promosi dari mulut ke mulut dalam format elektronik, yang adalah strategi maketing yang berkaitan dengan menciptakan pesan online yang orisinal dan cukup menghibur yang mendorong konsumen untuk menyampaikan pesan ke konsumen lainnya, menyebarkan pesan dalam web seperti virus secara gratis tanpa membebani si pengiklan (Howard, para. 1). Cara pemasaran ini secara umum sangat bergantung pada teknologi Internet, dengan konsumen sangat memahami penggunaan Internet dan menggunakan Internet sebagai sarana berkomunikasi sehari-hari.

Viral marketing dan viral advertising mengacu pada teknik-teknik pemasaran yang menggunakan social networks yang sudah ada untuk meningkatan brand awareness melalui proses self-replicating viral processes dengan penyebaran yang dapat dianalogikan seperti pola penyebaran virus biologis maupun virus komputer. Sehingga viral marketing dapat disebut juga fenomena marketing yang memfasilitasi dan mendorong masyarakat untuk menyebarkan pesan-pesan marketing secara sukarela.

Kriteria pendukung yang harus diperhatikan dalam viral marketing menurut Wiranaga (2003:97) adalah sebagai berikut: produknya berkualitas dan memang diperlukan oleh konsumen, bukan produk yang mengada-ada, atau terlalu asing bagi konsumen, apalagi yang masih controversial; harga produk bersaing dengan merek lain di toko atau di supermarket pada umumnya; program yang ditawarkan kepada konsumen bersifat sederhana dan mudah dimengerti; memberikan bonus minimal enam level, agar bisa mendapatkan bonus yang berarti; bonus bersifat residual, bukan hanya satu kali saja tapi berkelanjutan sesuai dengan penghasilan perusahaan penyelenggara program; tidak ada target menjual atau target point apapun, apalagi target penjualan downline; tidak ada syarat jumlah downline ataupun jabatan downline; tidak ada syarat pembayaran kepersertaan, biaya pendaftaran, atau syarat iuran apapun; tidak ada diwajibkan ikut seminar atau pelatihan tertentu dalam bentuk apapun; syarat belanja sesuai dengan kebutuhan wajar sebagai konsumen; pengorbanan maksimal anda hanyalah mengganti merek dari yang biasa ke merek yang memberikan program.

Kelebihan utama viral marketing menurut Richardson: (1) Internet telah menyatukan jutaan orang didunia cukup hanya dengan menekan tombol; (2) Cepatnya penyebaran informasi melalui Internet tidak bisa dibandingkan dengan sarana informasi lainnya. Pengaruh eksponen Internet sangat unik. Hanya dalam hitungan detik, sebuah pesan bisa dibaca oleh banyak orang di seluruh dunia; (3) Kekuatan viral marketing membuat biaya yang dikeluarkan untuk menyebarkan informasi itu sangat 
kecil; (4) Viral marketing mempunyai korelasi dengan merek yang sudah terkenal, penggunaan website, dan kesetian pelanggan. Hal ini disebabkan oleh proses referal yang terdapat pada hubungan yang berlandaskan atas rasa percaya; (5) Viral marketing memberikan kredibilitas instan pada perusahaan atau produk dan pengguna jasa marketing yang paling ramah melalui pengiriman pesan; (6) Viral marketing bisa diukur, menawarkan kesempatan pada marketer untuk melacak dan menganalisis keefektifan kampanye yang sudah dilakukan.

Sedangkan kelemahan viral marketing: (1) Ketergantungan pada triggers (pemicu utama viral marketing yang dapat terdiri dari berbagai media). Tanpa pemicu yang mampu menarik minat konsumen, pesan yang disebarkan tidak akan melalui proses replikasi dan akan mati; (2) Sangat susah untuk dikendalikan dan diawasi, dengan proses replikasi yang cepat dan penyebaran yang luas, menyebabkan perusahaan atau ahli pemasaran kehilangan kendali akan isi pesan yang disampaikan.

\section{Integrated Marketing Communications (IMC) (dalam Haspritareni, 2011)}

Integrated Marketing Communication atau IMC merupakan proses lintas fungsional untuk perencanaan, pelaksanaan dan pemantauan brand communications yang dirancang untuk memperoleh, mempertahankan dan meningkatkan jumlah pelanggan. IMC merupakan lintas fungsional karena setiap hubungan komunikasi yang terjalin dengan pelanggan dapat membangun brand image. Social media adalah pengiring untuk awareness and point of purchase campaigns yang sudah ada, bukan sebagai pengganti. Fokus teknis pada social media yang digunakan hanya sebagian dari apa yang tersedia untuk digunakan dalam upaya IMC secara komprehensif dan keseluruhan.

Dengan menggunakan TV, radio, direct mail, sports dan marketing event, maka memunculkan percakapan untuk mengelola ekspektasi dan menciptakan awal dari permintaan. Kemudian, percakapan yang dihasilkan oleh pengalaman langsung dengan merek, produk atau layanan tersebut memperkuat pesan berdasarkan minat dan komentar orang lain.

\section{HASIL DAN PEMBAHASAN}

Memasuki Abad 21 hampir semua aspek lingkungan kehidupan berubah dengan cepat, sehingga perusahaan harus menggunakan cara baru dalam melakukan pemasaran terhadap usaha mereka, selain menggunakan yang cara lama. Pemasaran tidak lagi menggunakan cara penyebaran brosur, pamflet dan sebagainya, akan tetapi menggunakan cara yang baru, dimana dapat menarik perhatian bagi calon konsumen secara langsung, juga dengan cara tidak langsung. Salah satunya dengan cara menggunakan dengan baik media sosial yang ada sekarang untuk melakukan pemasaran terhadap calon konsumen.

\section{Tantangan dan Peluang Social Media Digunakan bagi Perusahaan}

Tantangan yang dihadapi bagi perusahaan-perusahaan adalah bagaimana memanfaatkan social media dengan baik untuk membantu mengembangkan usaha yang dimilikinya. Saat ini belum ada petunjuk dalam bagaimana memanfaatkannya juga mengukur kesuksesan dari sebuah social media yang dipakai. Karena jika terdapat petunjuk pengukuran dan penggunaannya, social media akan dapat membantu dalam memanfaatkannya untuk pemasaran produk atau jasanya ke konsumen. Apalagi sebagian masih meragukan kemampuan social media dalam menciptakan awareness, brand image atau membantu pertumbuhan penjualan. Banyak perusahaan dan entrepreneur masih mengandalkan media-media konvensional yang memang sampai hari ini masih memberikan dampak yang besar. 
Ada juga beberapa perusahaan yang tidak dapat mengukur efektivitas social media karena mereka berpikir bahwa semua ini adalah gratis, atau untuk saat ini mereka hanya mengeluarkan budget untuk social media dalam jumlah kecil. Banyak berpendapat bahwa dengan biaya yang kecil, kesalahan yang dibuat tidak terlalu berisiko. Padahal walaupun gratis, dalam skala kecil perusahaan harus memiliki staf untuk memelihara akun social media mereka tersebut. Bahkan pada masa mendatang, perusahaan social media akan memaksa mereka untuk membayar dalam jumlah yang banyak untuk tetap bisa memakai fasilitas dari social media. Akibatnya mencari konsumen baru akan semakin sulit karena mereka menyadari bahwa mereka perlu target pasar yang lebih tepat. Pada akhinya mereka memilih untuk membayar kepada perusahaan social media.

Masih banyak perusahaan yang tidak dapat memahami alat pengukuran dalam bidang social media. Ini yang menjadi alasan untuk tidak melakukan pengukuran, karena hal ini masih relatif baru. Karena alat ukur yang umumnya dipakai oleh para pemasar terhadap Social Media untuk sekarang ini baru melihat berapa jumlah follower dari akun Twitter milik entrepreneur atau perusahaan, berapa penambahan follower-nya, berapa jumlah fans dari akun Facebook, berapa yang aktif memberi komentar, berapa jumlah kunjungan di situs tersebut yang masuk melalui akun Facebook atau Twitter, dan lain-lain. Para pemasar lebih tertarik dengan pengukuran yang bersifat taktis dan jangka pendek. Maka dari itu mereka lebih tertarik dengan berbagai pengukuran yang ada di Internet seperti tweetreach.com, twettgrader.com, alexa.com, dan sejenisnya. Itu baru dari pemasar, jika dari tingkat manajer pemasaran atau manajer komunikasi, mereka lebih tertarik dengan pengukuran yang bersifat menghitung biaya dan manfaat yang diperoleh seperti cost per mille (CPM), click through rate (CTR), atau cost per click (CPC).

Cost per Mille (CPM) (Wikipedia, 2013) bertujuan untuk membandingkan biaya untuk melakukan pemasaran dengan menggunakan berbagai macam media. Dengan melakukan ini, perusahaan bisa membandingkan media yang efektif untuk dilakukan pemasaran, baik dalam tahap permulaan dan setelah melakukan kegiatan pemasaran. Perhitungan CPM dilakukan dengan membagi biaya pemasaran dengan penerimaan dari para konsumen yang melihat pemasaran di media tertentu. Sehingga makin banyak masukan konsumen, dalam arti melihat iklan di social media tertentu, akan memberikan hasil yang lebih baik. Hal itu menandakan bahwa iklan di media tersebut telah memberikan atau memasarkan ke konsumen lebih baik dibandingkan dengan media lainnya.

Click through Rate (CTR) (Wikipedia, 2013) adalah cara mengukur kesuksesan dari sebuah iklan pemasaran online untuk situs tertentu, dalam hal ini adalah social media yang digunakan. Dengan tujuan menghitung seberapa banyak pengguna yang mengklik untuk iklan atau link tertentu yang ada di situs tersebut.

Cost per Click (CPC) (Wikipedia, 2013) atau yang dikenal juga dengan nama Pay per Click (PPC) adalah cara pemasaran Internet yang dilakukan dengan tujuan untuk membawa konsumen ke situs lainnya langsung dengan cara mengklik link yang ada, dan pemasang iklan akan membayar langsung juga ke pemilik situs setiap saat link-nya diklik. Menggunakan keywords yang dapat membantu mencari pangsa pasar, yang dapat dicari di search engine yang ada di Internet, sehingga bisa membawa konsumen langsung ke situs yang diinginkan karena menawarkan produk atau jasa yang ingin dibelinya.

Menurut Irawan D, (2011) salah satu pengukuran strategis yang mulai menarik perhatian baik bagi para pelaku pemasar, atau entrepreneur dan perusahaan adalah yang berhubungan dengan mention di social media. Sudah terdapat beberapa software yang beredar di pasar dapat membantu untuk mengukur positive mention, neutral, atau negative mention dari semua percakapan konsumen di social media. Hal ini penting untuk membangun merek sebuah perusahaan dibandingkan dengan merek-merek pesaingnya. Yang dikatakan oleh para konsumen di social media dapat dijadikan acuan yang cukup akurat terhadap penjualan dan pangsa pasar merek tersebut pada masa mendatang. Dengan melakukan pengukuran yang bersifat terus menerus, perusahaan mampu melacak pergerakan naik atau 
turunnya kekuatan dari sebuah merek. Merek-merek yang mempunyai tingkat intensitas mention yang tinggi dan positif dibandingkan merek pesaingnya dapat memberikan gambaran bahwa merek tersebut mempunyai brand image yang kuat dan tingkat loyalitas yang tinggi. Konsumen yang memberikan positive mention adalah konsumen yang puas dan loyal.

Bagi perusahaan, pengukuran ini penting karena menyangkut konsumen yang menjadi aset bagi sebuah merek. Pengalaman konsumen, keterlibatan konsumenm dan efek viral dari konsumen ini akan sangat memengaruhi tingkat loyalitas konsumen. Dan hal ini pasti akan memengaruhi penjualan, pangsa pasar, dan keuntungan usahanya. Selain melalui mention, juga berdasarkan investasi dan tingkat return yang akan didapatnya dengan menggunakan social media untuk usahanya. Untuk mengukur tingkat Return of Investment (ROI) prinsip perhitungannya tetap sama, yang dihitung untuk biaya komunikasi dan promosi adalah hasil selisih antara hasil investasi dikurangi dengan biaya investasi untuk komunikasi, dibagi dengan total investasi untuk komunikasi. Yang menjadi permasalahan untuk perhitungan ini adalah dalam menghitung hasil investasi yang diperoleh oleh sebuah merek dari produk atau jasa yang dimiliki perusahaan-perusahaan tersebut. Terdapat dua macam pengelompokkan yaitu jika untuk mengukur jangka pendek, besar hasil investasi sama dengan biaya investasi pada periode tertentu. Satunya lagi untuk mengukur jangka panjang, maka yang digunakan adalah total keuntungan yang diperoleh selama periode tertentu ditambah dengan kenaikan ekuitas merek tersebut sebagai akibat dari penggunaan aktivitas komunikasi di social media.

Selain menggunakan perhitungan ROI, dapat juga menggunakan perhitungan Engagement Rate (ER), dengan mengukur seberapa baiknya fan atau follower berinteraksi dengan konten social media yang dibuat (Wikipedia, 2013). Pengukuran terhadap satu posting di social media berdasarkan likes, comments dan share yang dilakukan di posting tersebut.

Untuk saat ini, metode pengukuran ekeftivitas dari suatu social media yang akan digunakan oleh perusahaan dalam melakukan pemasaran tidak ada metodenya. Pengukuran masih bersifat jangka pendek dan untuk mengubahnya menjadi jangka panjang tinggal menghitungnya dalam waktu periode tertentu. Umumnya yang dilakukan mereka adalah untuk mengukur jangka pendek, padahal sebaiknya pemasaran yang diterapkan dalam bentuk jangka panjang.

\section{Perkembangan Metode Pengukuran Efektivitas Social Media}

Dalam perkembangannya, metode untuk mengukur efektivitas dari penggunaan social media berkembang sangat pesat seiring dengan munculnya inovasi terbaru pada teknologi social media. Salah satunya situs Facebook dengan aplikasinya Facebook insight yang dalam perjalananya sering berubah-ubah mengikuti tren pengguna dan menampilkan fitur-fitur baru yang sebelumnya tidak pernah terbayangkan. Sepanjang perubahan tersebut terjadi, maka selama itu juga bentuk evaluasi, analisis atau laporan social media berubah-ubah.

Sebelumnya bentuk dari laporan social media hanya mengikuti seperti sebuah laporan kinerja sebuah web, sangat identik dengan Google Analytic. Namun, untuk saat ini social media tidak bisa diperlakukan layaknya hanya sebuah jenis website. Laporan pada social media tidak sesederhana memantau berapa banyak pengunjung yang datang ke akun Facebook fanpage perusahaan. Bentuk laporan social media saat ini cukup kompleks. Untuk itu, Primaretha (2012) menciptakan bentuk tahapan analisis social media yang digunakan untuk mengukur kesuksesan dan efektifitas dari setiap kampanye social media yang dikerjakan bersama dan tim social media di Virtual Consulting. Berikut ilustrasi model analisis social media yang disebut sebagai 3 layers of social media analysis: 


\section{Layers of Social Media Analysis}

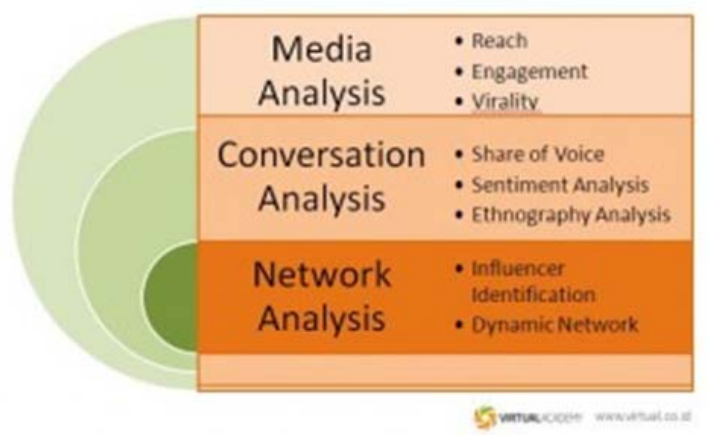

Gambar 2 Tiga Tahap Analisis di Social Media (Sumber: Primaretha, 2012)

\section{Media Analysis}

Jika disamakan dengan buah, analisis media merupakan lapisan kulit dari buah tersebut. Analisis media merupakan tahapan pertama dari sebuah evaluasi atau analisis untuk mengukur kinerja sebuah akun brand atau pribadi kita di social media. Analisis Media terdiri dari 3 matriks utama yaitu reach, engagement, dan virality. Reach mengukur jangkauan kita terhadap audiens, contohnya adalah total fans atau followers, total views/unique views dan informasi mengenai demografi atau behavior dari jangkauan audiens tersebut. Kemudian matriks kedua adalah engagement. Matriks ini berusaha untuk mengukur seberapa besar aktivitas dalam membuat konten juga dengan seberapa banyak konten tersebut mendapatkan feedback dari audiens. Yang terakhir adalah Virality. Ini matriks khusus untuk mengukur sebuah kampanye di social media; contohnya adalah hashtag \#NutriSariSocialGarden yang dipantau dari sisi berapa banyak yang me-retweet hashtag tersebut dan kemudian berapa banyak impresi yang dihasilkan dari banyaknya orang yang me-retweet tentang tweet yang berisikan hashtag tersebut.

\section{Conversation Analysis}

Tahapan analisis ini masih sering kali ditinggalkan karena mungkin ketidaktahuan atau teknologi yang belum cukup memadai. Contohnya seperti ada sebuah akun brand di social media yang memiliki banyak fans atau followers dan memiliki jumlah mentions yang sangat banyak tiap harinya. Namun pernahkah melihat bahwa dari sekian banyak wall, comments, mentions yang masuk tersebut berbicara tentang apa dan bagaimana tone-nya? Analisis pada tahapan ini berusaha untuk memahami kata-kata yang paling sering digunakan oleh audiens ketika berusaha berkomunikasi dengan. Kemudian, isu-isu yang menjadi concern mereka di begitu banyak tweet dan walls di akun social media tersebut.

Tidak hanya berhenti di situ, diperlukan mengukur dengan analisis sentiment. Dengan tiga indikasi tone positif, netral, dan negatif, berusaha memahami emosi dari konsumen dengan tiga tolak ukur tersebut. Bisa saja kehadirannya di social media hanya sebagai pelampiasan dari kekecewaan dari pelanggan yang tidak puas, perlu diketahui. Hal terakhir dari analisis tahapan ini adalah menggunakan pisau analisis etnografi. Analisis ini berbentuk kualitatif dan hasil analisisnya pun berupa narasi/katakata yang hendak menjelaskan bagaimana keunikan dari persepsi atau perilaku audiens kita terhadap brand tersebut di social media.

\section{Network Analysis}

Salah satu tujuan brand hadir di social media adalah untuk menghimpun sebuah komunitas yang menyukai brand tersebut. Komunitas merupakan alat yang sangat ampuh untuk memengaruhi 
pelanggan dan calon pelanggan tersebut. Orang-orang tentunya pasti akan mudah terbujuk percaya jika yang memberitahukan kebaikan sebuah produk adalah teman, keluarga, atau tokoh masyarakat yang dikagumi. Untuk itu, analisis pada tahapan ini berbicara mengenai tentang sejauh mana keberhasilan dalam memengaruhi influencer dan jaringan pertemanannya di social media.

Matriks pertama adalah influencer identification dan measurement. Diperlukan mengetahui siapa saja orang-orang yang memiliki influence tinggi di bidang atau industri dari brand tersebut. Influencer tidak harus artis, karena bisa saja dia seseorang yang tidak pernah muncul di TV atau media massa lainya namun sangat dikenal di social media. Influencer juga bukan buzzer karena sekarang audiens pun sudah semakin cerdas ketika seorang buzzer mulai nge-tweet karena dibayar oleh brand tertentu. Kemudian ada Dynamic Network sebagai pengukuran yang kompleks karena sudah berbicara tentang konsep atau teori dari analisis jejaring sosial. Di dalam pengukuran ini akan nada visualisasi dari ego network (jejaring pribadi) dengan para influencer yang telah menjadi follower brand tersebut.

Selain yang di atas, ada banyak cara untuk mengukur efek dari media sosial. Ada alasan bagus untuk tahu jika perusahaan-perusahaan menggunakannya dengan benar, atau jika bahkan layak menggunakannya untuk beberapa perusahaan, media sosial mungkin tidak berbuat banyak. Nilai media sosial yang tersedia bagi perusahaan adalah relatif untuk beberapa hal: upaya yang diletakkan seterusnya dalam menggunakan media sosial, konsistensi penggunaan, dan target khalayak yang telah ditetapkan perusahaan.

Berikut adalah beberapa cara mengukur efektivitas, hasil, dan potensi kekurangan dari alatalat media sosial (Danudjaja, 2010). Pertama, trafik, ada beberapa cara untuk memantau trafik situs atau blog sebuah perusahaan, beberapa lebih dapat diandalkan daripada yang lain: (a) analitik, adalah cara bagus untuk memonitor asal trafik berasal. Ini juga dapat menunjukkan lama waktu pengunjung tinggal, lokasi calon konsumen atau pelanggan menjelajahi situs perusahaan, atau jika menggunakan mesin pencari untuk datang ke situs perusahaan tersebut. Analitik adalah cara bagus untuk memperlihatkan link yang perusahaan yang buat jika dapat membangkitkan trafik; (b) kounter pengunjung, untuk menunjukkan jumlah pengunjung situs atau blog perusahaan tersebut, asal calon konsumen atau pelanggan.

Hal bagus tentang alat-alat di atas adalah bahwa perusahaan dapat memetakan tempat pengunjung pergi dan alur yang diambil oleh calon konsumen atau pelanggan di situs atau blog perusahaan, link yang paling banyak diklik dan website yang mereka tuju setelah datang ke halaman arahan (landing page).

Kedua, jangkauan dan interaksi social media, dapat dilakukan dengan beberapa cara: (a) komentar, meskipun data menunjukkan bahwa sebagian besar pengunjung dianggap "pengintai" (pengunjung yang tidak berpartisipasi dalam komunitas online, blog, atau grup, tetapi hanya mengintai situs), situs dan blog perusahaan masih bisa mendapatkan komentar. Konten juga dapat menghasilkan komentar di situs lain dari pengguna; (b) penyebutan di situs jejaring sosial dan bookmark untuk situs atau blog perusahaan, hal ini dapat mencakup Twitter, Facebook, LinkedIn, Digg, Technorati, StumbledUpon, dan lain-lain. Monitor situs tersebut, dan konten perusahaan dengan mudah bisa dishare ke calon konsumen atau pelanggan terjadi; (c) "pengintai” berbalik menjadi pengunjung yang interaktif. Melihat jika ada semacam kenaikan dalam reaksi, komentar, dan berbagi di alat bookmark dan jaringan sosial yang disebutkan di atas; (d) perubahan profil, di Twitter, perusahaan dapat melihat jumlah orang yang mengikuti perusahaan tersebut. Hal ini membantu untuk menghidupkan terus menerus popularitasnya; (e) RSS feed berlangganan dan pendaftaran newsletter, jika perusahaan memberikan e-book gratis, perusahaan dapat memilih untuk menggunakan bentuk yang membuat orang-orang mendaftar ke mailing list, atau dapat menawarkan newsletter yang keluar setiap minggu. Jumlah pertumbuhan email yang masuk dapat mengidikasikan upaya media sosial perusahaan terbayar. 
Ketiga adalah peningkatan penjualan dan calon konsumen. Pada tingkat yang sangat dasar, perusahaan juga dapat mengukur dampak dari social media melalui peningkatan penjualan dan calon konsumen (perubahan dari calon konsumen ke konsumen tetap). Walaupun sangat sulit untuk mengukur asal penjualan dan potensi penjualan tanpa menanyakan langsung ke mereka, memantau penjualan online dengan analistik, dan lain-lainnya, perusahaan bisa membuat riset kecil ke calon konsumen atau pelanggan. Kuncinya, untuk mengevaluasi semua hal tersebut dan melihat mereka membantu penjualan. Perubahan satu variabel pada suatu waktu dapat membantu menunjukkan dengan tepat upaya-upaya yang menjadi paling efektif.

\section{SIMPULAN}

Melihat metode yang ada sekarang dalam menghitung atau mengukur keefektivitas dari sebuah social media untuk digunakan oleh entrepreneur atau perusahaan dalam melakukan kegiatan pemasaran, maka dapat disimpulkan sebagai berikut. Pertama, kehadiran teknologi web 2.0. dan aplikasi social media Internet telah membawa perubahan perilaku para pengguna dalam menggunakan Internet. Perubahan yang lebih mengarah interaksi pengguna sekarang lebih sosial, dan jika dilihat dari sudut pandang para entrepreneur dan perusahaan maka untuk lebih mendekatkan diri ke konsumen dengan menggunakan metode pemasaran yang lebih sosial. Hal ini memberikan tantangan baru bagi pelaku bisnis untuk melakukan pemasaran melalui Social media. Kedua, metode pengukuran keefektivitas dari sebuah Social media untuk digunakan oleh entrepreneur atau perusahaan masih belum ada yang terstandardisasi, dan masih mengalami perkembangan seiring dengan berkembangnya teknologi informasi, sehingga harus mengadaptasi perubahan yang terjadi. Ketiga, metode yang ada kebanyakan digunakan oleh entrepreneur atau perusahaan lebih mengarah ke jangka pendek, padahal untuk kebaikan atau perkembangan usaha yang dimiliki entrepreneur atau perusahaan sebaiknya berfokus untuk jangka panjang, sehingga bisa mengadaptasi setiap perubahan yang akan terjadi. Ketiga, untuk mendukung kegiatan pemasaran entrepreneur atau perusahaan, perlu dilakukan kegiatan pemasaran tidak hanya melalui cara konvensional atau yang lama, tetapi juga sebaiknya memanfaatkan social media untuk lebih menjangkau seluruh konsumen yang diinginkan. Keempat, belum ada standar untuk dilakukan metode pemasaran dengan menggunakan social media, sehingga terkadang banyak iklan pemasaran di social media tersebut tidak terlalu diperhatikan oleh pengguna apalagi mereka hanya ingin melihat-lihat saja. Kelima, perkembangan social media harus diikuti dengan kegiatan pemasaran yang bisa memadai perkembangan tersebut.

\section{Rekomendasi}

Pertama, pihak perguruan tinggi dan para ahli pemasaran, juga pemerintah terlibat untuk mendiskusikan cara pengukuran atau penggunaan social media yang baik dan bermanfaat dalam melakukan pemasaran. Dengan demikian, pihak perusahaan dapat melakukan kegiatan pemasaran dengan menggunakan social media sebagai sarana secara baik. Kedua, perusahaan-perusahaan sebaiknya jangan hanya menggunakan satu atau dua metode pengukuran social media yang ada sekarang saja. Akan tetapi, perusahaan dapat memakai semuanya untuk lebih bisa mengakomodasi kebutuhan dan juga melihat metode pengukuran Social media yang baru. Ketiga, adanya suatu standardisasi pengukuran social media akan membantu perusahaan dalam melakukan kegiatan pemasaran melalui social media dengan lebih baik. 


\section{DAFTAR PUSTAKA}

Anonim. (2009). Viral Marketing: Definisi, Kriteria Pendukung, Kelebihan dan Kelemahan Viral Marketing. Diakses 01 Januari 2013 dari http://jurnal-sdm.blogspot.com/2009/09/viralmarketing-definisi-kriteria.html

Chandra, R. (2011). Pengaruh Penggunaan Social Media Berbasis Teknologi Web 2.0 terhadap Keefektifan Komunikasi Pemasaran Pada Komunitas Adination of Runners Indonesia. Jakarta: Universitas Bina Nusantara.

Danudjaja, R. S. (19 November 2010). Cara Mudah Mengukur Efektivitas Sosial Media. Diakses 6 Juni 2013 dari http://rinisdanudjaja.blogspot.com/2010/11/cara-mudah-mengukur-efektivitasmedia.html\#.UbAym9ixk3I

Evans, D. (2008). Social Media Marketing: an Hour a Day. New Jersey: John Wiley \& Sons.

Haspritareni, T. (2011). Case Study: Efektivitas Strategi Social Media Marketing pada PT. Toyota Astra Motor. Skripsi tidak diterbitkan. Jakarta: Binus Business School.

Irawan D. (2011). Social Media Measurement. Marketing.

Ivan Mulyadi. (2011). Investasi Perusahaan dalam Social Media Menurut Eurocom 2011. Digital Marketing.

Primaretha, A. (6 Februari 2012). 3 Tahap Analisis di Social Media. Diakses 05 Juni 2013 dari http://www.virtual.co.id/blog/social-media/3-tahapan-analisis-social-media/

Wahyudi, 18 Oktober (2009). Apa itu Internet Marketing ? Bagaimana Internet Marketing Bekerja. , diakses 01 Januari 2013 dari http://duniaebook.wordpress.com/2009/10/18/apa-itu-Internetmarketing-bagaimana-Internet-marketing-bekerja/

Wicaksono, K. C. B. (2002). Analisis Perbedaan Brand Image Situs Berita Online Lokal. Jakarta: Universitas Bina Nusantara Program Studi Magister Manajemen Sistem Informasi.

Wikipedia. (28 Januari 2013). Social Media Measurement. Diakses 01 Januari 2013 dari http://en.wikipedia.org/wiki/Social_media_measurement

Wikipedia. (29 Januari 2013). Social Media. Diakses 01 Januari 2013 dari http://en.wikipedia.org/wiki/Social_media 